\title{
B. Ed. First Year Students' Motives for Learning English
}

\section{Lok Raj Sharma}

Associate Professor of English

Head of Faculty of Education

Makawanpur Multiple Campus, Hetauda, Nepal

Email: lokraj043@gmail.com

DOI: https://doi.org/10.3126/irjmmc.v2i3.40085

Received: August 29, 2021; Revised \& Accepted: September 27, 2021; Published: September 29, 2021

(C) Copyright: Sharma (2021).

\section{ABSTRACT}

This research article attempts to evaluate B.Ed. first year students' major motives for learning English. A cross-sectional survey design was adopted to accomplish the research study. The twelve questions as a data collection tool were administered to the students across three campuses of Makawanpur District, Nepal in the Academic Year 2019-2020.The study showed that a large number of the students learnt English to have good job opportunities in the country, whereas the smallest number of students learnt it to be tourist guides. The chisquare tests showed that there was statistically significant association between sex and the motives for learning it, whereas there was no statistically significant association between campuses and motives for learning it. The findings of the research study indicated that students learnt English for fulfilling differing purposes in their life. Their attitude towards learning English was found to be dissimilar.

Keywords: English, learning, motive, motivation,

\section{INTRODUCTION}

A motive is a reason for doing something. It is an incentive that causes a person to act in a certain way. There might be certain motives of students for learning English. This article aims at finding out the motives of students for learning this language. The students at campuses in Makawanpur come from heterogeneous backgrounds. They have dissimilar levels of understanding of English and varied aspirations that affect their motives for learning it. They have to learn it in spite of their cognitive disparities. B.Ed. students in the Faculty of Education under Tribhuvan University learn English education as a compulsory as well as an optional subject. General students at the bachelor level in the Faculty of Education learn English grammar and literature in the first year; whereas the students majoring English learn grammar, literature and linguistics in the course of study, therefore the fundamental reason for learning English is to succeed in the examination. Besides this reason, this research study attempts to find out other reasons for learning it.

The researcher developed one questionnaire with 12 options that were related to the motives for learning English to elicit the primary data from the students. The study was delimited within three campuses. Only 206 students out of 442 were selected as respondents through a simple random method by maintaining the confidence level $95 \%$, and the margin of error 5\% (two-tailed). This article is useful to English course developers and English teachers.

\subsection{Status of English in Nepal}


English holds a prestigious position in Nepal despite the fact that it is a foreign language for the Nepalese students. Bista (2011) considers English as "a foreign language for the speakers of Nepali” (p.3). Concerning the entry of English into Nepal, Giri (2015) mentions that English was in use before the beginning of the formal schooling in the early seventeenth century in Nepal, however it formally entered into Nepal during Ranarchy with the establishment of Durbar School in 1853. Jung Bahadur Rana's visit to Europe in 1850-51 and his observation of the achievements of the British inspired him to introduce English education in Nepal. He was very much impressed by their achievements. Khatri (2019) asserts the fact that "the formal introduction of English in Nepalese school education system is closely connected with the rise of Rana rule in the 19th century" (p. 45). Similar opinion is expressed by Sharma (1990) as he points out "after his trip to Europe, Jung Bahadur realized the importance of English for communication with the outside world and felt that his sons should be given a western education" (p. 3), but teaching or education was first limited to the children of Rana families. Teaching was done at Durbar school, which was the first modern school in Nepal. Teaching was most likely modeled on the traditional British style. Vir ( 1988, as cited in Poudel, 2016) takes it as a shift to a modern system of education. With the establishment of Trichandra College in 1918, teaching English courses took place under the supervision of Patana University, India (Bista, 2011). There is no apparent evidence regarding teaching and learning methods employed that time.

When public schools were opened in the 1950s and Tribhuvan University was established in 1959, students slowly started learning English. The development of English language teaching and learning in Nepal reached its climax in the 1990s as this was the period of the opening of Nepal to tourism. Ojha (2018) highlights a liberal policy of the government regarding private schools and affirms that "after the restoration of democracy in Nepal in 1990, governments adopted a liberal policy to allow the establishment of private schools" ( $p$. 190). These schools were opened in district headquarters and other cities, used English as the exclusive medium of instruction and made the language accessible to people who could afford to pay the tuition fees.

Use and importance of English is increasing day by day in Nepal. English is now superseding the importance of Nepalese language, and, over the last three decades. It has been prioritized in the educational curriculum. Bhattarai (2006) and Maharjan (2009) assert that English still has the status of a foreign language in Nepal, because there are still no communities that use English for day to day conservations.

In the last three decades, English language teaching has improved greatly in Nepal. The change can be noticed in terms of the structure of education, pedagogies and institutions of higher learning (Bista, 2011). However, while gross enrolment of children in school has increased rapidly, the quality of public schools has deteriorated and the private sector commands authority in the school system, based on better results in the School Leaving Certificate (SLC) or School Education Examination (SEE). The growth in the private sector came about due to the prevailing school liberalization policy in 1998 (Thapa, 2011) and the demand for admission to private schools has since been widespread, especially from well-off families. 
Concerning the learning of English, Giri (2010) asserts that "the English language occupies an impeccable and indispensable place in the socio-economic system, and therefore, the drive for its learning is paramount... English is, therefore, socially, economically and educationally elevated higher than all other local languages" (pp. 64-65). The position of English in Nepal is high as Awasthi (3003, as cited in Bhattarai \& Gautam, 2007) affirms:

Nepal is providing education through six Universities about 1000 constituent and affiliated colleges, some 1500 higher secondary schools and 42100 schools of which 7154 are privately run and the rest are publicly run. English occupies a prominent position in the total education system in Nepal. (p. 32)

In the view of Sharma (2006), English has been offered as a compulsory subject from the primary level up to Bachelor level. There is a provision of English as an optional subject from grade nine to twelve under the curriculum of school education of Nepal. English is considered as a prestigious foreign language in Nepal; therefore people who can read, write and speak in English are respected and valued.

\subsection{English at university level}

Tribhuvan University, which is the first university in Nepal, was established in 1959. It gave noticeable priority to its curriculum in English. The National Education System Plan (NESP 1971-76) was implemented and it introduced English language teaching (ELT) formally from the school level to the university level of education. This Plan brought a radical transformation in the education system of Nepal. Unfortunately, that Plan decreased the weight age of English courses from 200 marks to 100 marks as set up by earlier system. It also reduced the credit hours of English from 15 to 10 from high school to university levels (Malla, 1977). The Plan made English a compulsory school subject no more, but made a provision to opt for any of the United Nations languages such as Chinese, French, Spanish, and German, not necessarily English. Awasthi (1979) mentions that majority of educators and students were in favors of "continuing English in secondary level" (p. 64). Meanwhile, the government made its decision to "switch over from English to Nepali" as a medium of instruction in schools (Malla, 1977, p. 69). Later in 1981, Tribhuvan University brought a change in the structure of English syllabi allocating weight age of 200 marks instead of 100 to the campus level English. The university also discontinued the semester system and reintroduced the annual system of teaching and assessment (Malla, 1977).

The teaching and learning of English has been widening day by day. It has been taught in the Faculty of Management at the Bachelor's Levels such as the Bachelor of Business Studies (BBS) in the first and second years, Bachelor of Business Management (BBM) and Bachelor of Business Administration (BBA) in the first, second and third semesters. It is taught even at the Master level in the Faculty of Management after the implementation of the semester system under Tribhuvan University, Nepal. Several text books of the school and campus levels are written in the English language. Examination questions are set in the English language excluding the questions of the Nepali subject.

In case of higher education, English is offered as one of the elective subjects under the Faculty of Education (FoE) in B.Ed. and M.Ed. and under the Faculty of Humanities and Social Sciences (FoHSS) in B.A. and M.A. Similarly, English is taught for Specific Purposes 
(ESP) in the Faculty of Law, in the Institutes of Medicine, Engineering, Agriculture, Forestry, College of Banking and Financial Studies.

\subsection{English for B.Ed. students}

Faculty of Education under Tribhuvan University is a leading institution in the field of teacher education in Nepal. In the day of inception, this faculty had the two-year programme, and it implemented the three- year programme from 1996 to 2015. It has been implementing the four-year programme since 2015. All the B.Ed. first year students have to study English as a compulsory subject which involves grammar and literary texts; whereas the students whose major subject is English education have to study two subjects: Reading Writing and Critical Thinking, and Foundations of Language and Linguistics. All students do not need to study English from the second year. Only the students with major English Education have to study English. They study three subjects in their second year: English for Communication, Expanding Horizon and Academic Writing. They study three subjects in the third year: Critical Readings in English, Mass Communication and English Language Teaching. Similarly, in the fourth year they need to two subjects in English Education: Research Methodology in English Education and Exploration in English. All the contents intended to teach the students are very useful to them. The courses encourage them to be critical, creative and diligent. They are expected to learn language, linguistics and literature well. The English courses prescribed for the students in the Faculty of Education are very useful, practicable and standard.

\subsection{Objective of the study}

Objectives of the study are to:

- Evaluate the students' major motives for learning English cautiously.

- Examine the association of motives for learning English across the categories of sex and campus of the students.

\subsection{Hypotheses}

This research study involves two null hypotheses:

- There is no statistically significant association between the motives for learning English and the sex.

- There is no statistically significant association between the motives for learning English and the campus.

\section{LITERATURE REVIEW}

Literature review in this article includes English language attitude towards English, motivation, major motives for learning English The review also holds some writers' views on learning English and some empirical review regarding English language.

\subsection{Attitudes towards English}

Simply, attitudes towards English refer to the feelings people have about English. The research studies carried out to assess the students' attitudes towards learning English exposed students' positive attitudes towards learning it. The research studies carried out by Mohd Sallehhudin (1994) with 137 University Kebangsaan Malaysia English non-major undergraduates, Kaharan (2007) with 190 eighth grade students of a private primary school in Adana, Turkey, Chalak and Kassaian (2010) with 108 English translation major students at 
Islamic Azad University, Iran, Yang (2012) with 20 University Malaya Master students, Al Mamun, Rahman, Rahman and Hossain (2012) with 79 randomly selected non-major English undergraduate students from Khulna University, Bangladesh, Bobkina and Fernandez de (2012) with 72 EFL engineering students at the Technical University in Madrid, Chew (2013) with 111 students at the University of Malaya, China, and Tahaineh and Danna (2013) with 184 Jordanian EFL female undergraduates depicted that students had positive attitudes towards learning English.

\subsection{Motivation}

Learning depends on motivation. Motivation is one of the most appealing, complex variables used to explain individual differences in language learning. According to Ryan and Deci (2000) motivation is concerned with "energy, direction, persistence and equifinality-all aspects of activation and intention" (p. 69). Johnstone (1999) defines motivation as "a stimulant for achieving a specific target" (p. 146). Brewer and Burgess (2005) assume that motivation is "a basic and essential part of learning" (p. 24). Motivation as an internal state that arouses directs and maintains behaviour. Motivation as an internal process encourages students to develop positive attitudes towards learning things. Motivation holds the potentiality of energizing and guiding the students' behaviour in excess of time. Gardner (2006) asserts that "students with higher levels of motivation will do better than students with a lower level" (p. 251). Harmer (1990) writes that "motivation is some kind of internal drive that encourages somebody to pursue a course of action" (p. 3). Some students are driven to learn English by integrative motivation for assimilating themselves into English culture, while the other students are driven by instrumental motivation for their practical benefits.

Learning is regarded as a process of bringing some relatively enduring changes in the behaviour of the learners through experience and training. Pressey, Robinson and Horrocks (1967) consider learning as "an episode in which a motivated individual attempts to adapt his behaviour so as to succeed in a situation which he perceives as requiring action to attain a goal" (p. 232). Similar concept of learning is expressed by Crow and Crow (1973) who opine that "learning represents progressive changes in behaviour and it makes an individual able to satisfy his interests to attain a goal" (p. 225). Learning is purposeful and goal-oriented. It is a continuous process. Krashen (1985) distinguished language acquisition and language learning. He opines that acquisition is the "subconscious process identical in all important ways to the process children utilize in acquiring their first language" (p. 1); while for him learning is the "conscious process that results in knowing about language" (p. 1). Harmer (1990) affirms that "acquiring language is more successful and longer lasting than learning" (p. 31). But it is impossible for the Nepalese students to acquire language, because they are not exposed to English environment at home in their early stage. Brown (1994) asserts that "learning is retention of information or skill" (p. 7). We learn the English language for fulfilling some purposes in our life.

Gardner and Lambert (1972, p. 316) classified motivation into two types: integrative and instrumental. Integrative motivation means learning the language with the intention of participating in the culture of its people; whereas instrumental motivation implies that a learner learns the language in support of a purpose relating to occupation or further useful 
motives. These two types of motivation can affect and control the procedure and outcome of learning.

The research study carried out by Vaezi (2008) with 79 students studying at their first year at Berjand University in Iran indicated that Iranian students had positive orientations and attitudes towards English, and they were more instrumentally than integratively motivated to learn English. Similarly, the research study conducted by Bobkina and Fernandez de (2012) with 81 male students in the department of Petroleum Engineering at HUST, Yemen provided strong evidence that Yemeni undergraduate students were highly instrumentally motivated. With 266 students from 10 different secondary and high schools in Education Service Area 4, Saraburi Province showed that their instrumental motivation to learn English was very high. Furthermore, the research works carried out by Rehman, Bilal, Sheikh, Bibi, and Nawaz (2014) with50 students from intermediate level (25 males and 25 females) were taken from a private college of Sargodha concluded that the percentage of instrumentally motivated students was higher (i.e. 70\%) than integratively motivated students in learning English language. The present study result conformed the results of the previous studies on motivation.

\subsection{Major motives for learning English}

English is a prominent global language of education, science, technology, computer, tourism, diplomacy, world literature, philosophy, business, aviation and communication. Giri (2014) points out that English has been playing the role of lingua franca across diverse socioeconomic sectors interacting with the local languages through code mixing and codeswitching. English is spreading in a massive way in divergent fields of activities, and "this massive spread of English can be attributed to the various historical, political, cultural, economic and technological factors" (Shrestha, 2017, p. 2). As a result, the charm of learning English has been increasing day by day in the world.

Students' motives for learning English are not the same. Harmer (1990) asserts that students want to "know more about the people who speak it and the place in which it is spoken" (p. 2). Rao (2018) asserts that "English has become one of the most important academic and professional tools" (p. 1). Nishanthi (2018) views English as "a vital language for all kinds of professional and personal goals" (p. 871). In the view of Mahu (2012), learning English as a foreign language "allows us to fully appreciate the culture and its context of a country, it widens our understanding" (p. 374). The findings of the research carried out by Tabatabaei and Mokhtari (2014) depict the necessity "for university students to be able to read English language books, articles, journals, and internet sources related to their fields of study" (p. 1145).Boniadi, Ghojazadeh, and Rahmatvand (2013) maintain that "English plays an eminent role in higher education all over the world" (p. 48). All the attributes used to describe the English language indicates that English is a versatile language that has been used for occupational purposes, academic purposes and science and technology purposes. It has been used in politics, diplomatic affairs, religious books, philosophical books, literature and entertaining reading materials. 


\subsection{Empirical Review of Literature}

Research studies have shown the students' motivation for learning English. Mahreez (1994) carried out a research study on identifying the most common motivational factors with the sample of 130 undergraduate students at Universiti Utara Malaysia through using the questionnaire. The findings showed that the students were instrumentally oriented. They realized the significance of the English language.

Hedge (2000) in his book based on a research study investigated the motivation of 20 Japanese students who were studying English. The findings indicated that the most common motives for studying English as a second language were for communication with people overseas, finding employment in a high profile career, processing international information, and understanding other cultures.

A research study conducted by Al-Quyadi (2000) to investigate the psychosociological variables in the learning of English with the sample 518 major English students in the Department of English, Faculties of Education at Sana'a University in Yemen showed that the students had a high level of both instrumental and integrative motivation toward the English language.

A research study was carried out by Al-Tamimi and Shuib (2009) on attitudes towards learning the English language with the sample of 81 petroleum engineering students in the academic year 2006-2007 at Hadhramout University of sciences and technology. The data were collected through questionnaire and interviews. The results of questionnaire showed that $79 \%$ students learnt English because they wanted to be educated persons. They considered that the development of their country was possible mainly by educated people who knew English well.

Sali (2012) accomplished a research study using the teachers' ten statements test that was administered to 100 trainees in an ELT Department in Turkey. The study showed that those ELT trainees were driven by career motivation. Learning the English language was regarded as opening multiple chances for getting jobs.

Rehman, Sheikh, Bilal, Bibi and Nawaz (2014) carried out a research study by using quantitative research method with 50 intermediate students as a sample from a private college in Pakistan. In terms of gender, the group was divided involving 25 males and 25 females. A questionnaire was designed on Likert scale in order to collect data. The results showed that $70 \%$ students were instrumentally motivated and $24 \%$ were integratively interested in learning the English language.

Ahmed, Aftab and Yaqoob (2015) conducted a research study with the sample of 199 students at undergraduate level from University of Sargodha (UOS) Women Campus Faisalabad, Pakistan by administering a questionnaire on the four point Likert scale to the students. The results of the research showed that the highest percentage of students $(36 \%)$ strongly supported the opinion that they learnt English only for a job or some reward.

Akcay, Butuner and Arikan (2015) brought about a research study on reasons behind learning foreign languages with the sample of 20 Turkish students studying English at a private language school in Antalya, Turkey by administering the questionnaire to those students. The results depicted that $22.61 \%$ students learnt the English language for talking to 
foreigners or tourists, $16.67 \%$ for entertainment (songs, games, movies, etc.) , $15.48 \%$ for having better grades at school, $14.29 \%$ for English being a global language, $11.90 \%$ for having a better job/earning more money, $11.90 \%$ for living/working abroad, and $7.15 \%$ for enjoying learning English.

Goharimehr (2017) carried out a research study on identity, motivation and English learning with the sample of 22 Japanese male and female students in graduate and undergraduate levels who had taken English courses in Japanese universities. The Likert type questionnaire was administered to those students. The results indicated that $86.65 \%$ students would like to learn about the people and culture of English speaking countries, $69.15 \%$ asserted that studying English would help them have good relationships with friends, $77.5 \%$ assumed that studying English would make them able to create new thoughts, and $90.85 \%$ affirmed that being good at English would help them study other subjects well.

Students in Nepal learn English to be able to exchange their ideas, share experiences and acquire knowledge through English. Jha (1989) in his research stated the purpose of teaching English in Nepal as "an effort to enable them [learners] to exchange their ideas and views with those who use English and the same time to acquire knowledge, ideas, skills and techniques imparted formally and informally through English" (p. 76). They are eager to learn English, because it is an impressive channel of communication as mentioned by Malla (1977) that "it is enough for "establishing effective channels of communication with the rest of the world" (p. 12). Learning English has been essential to the Nepalese students to access standard books which are written English. Malla further viewed English as "a library language to have an access to textbooks, lectures, and journals" (p. 16). The students have realized need and importance of learning English to cope with the demand of time as Anderson and Lindkvist (2000) in their research studies revealed "there was a strong need for English in Nepal and the country needed well-trained teachers, improved textbooks, enough supplementary materials, and better evaluation system”. Use and importance of English in diverse fields of activity in the present situation has encouraged the Nepalese students to learn English.

\section{MATERIAL AND METHOD}

\subsection{Research Design}

A cross-sectional survey design was used to carry out the study. The researcher collected the primary data from the questionnaire to investigate the students' major motives for learning English cautiously.

\subsection{Population and Sample Size}

The population of the study consisted of 442 bachelor first year education students studying at three campuses namely, Makawanpur Multiple Campus (Campus A), Hetauda Campus (Campus B) and Hatiya Janapriya Campus (Campus C) in Makawanpur District of Nepal in the Academic Year 2019-2020.

The researcher selected 206 students through the simple random sampling technique (lottery method). The sample involved 142 girls and 64 boys. The sample size was determined by maintaining the confidence level 95\%, and the margin of error 5\% (two-tailed) by using the 
sample size determining software.https://fluidsurveys.com/university/survey-sample-sizecalculator/.

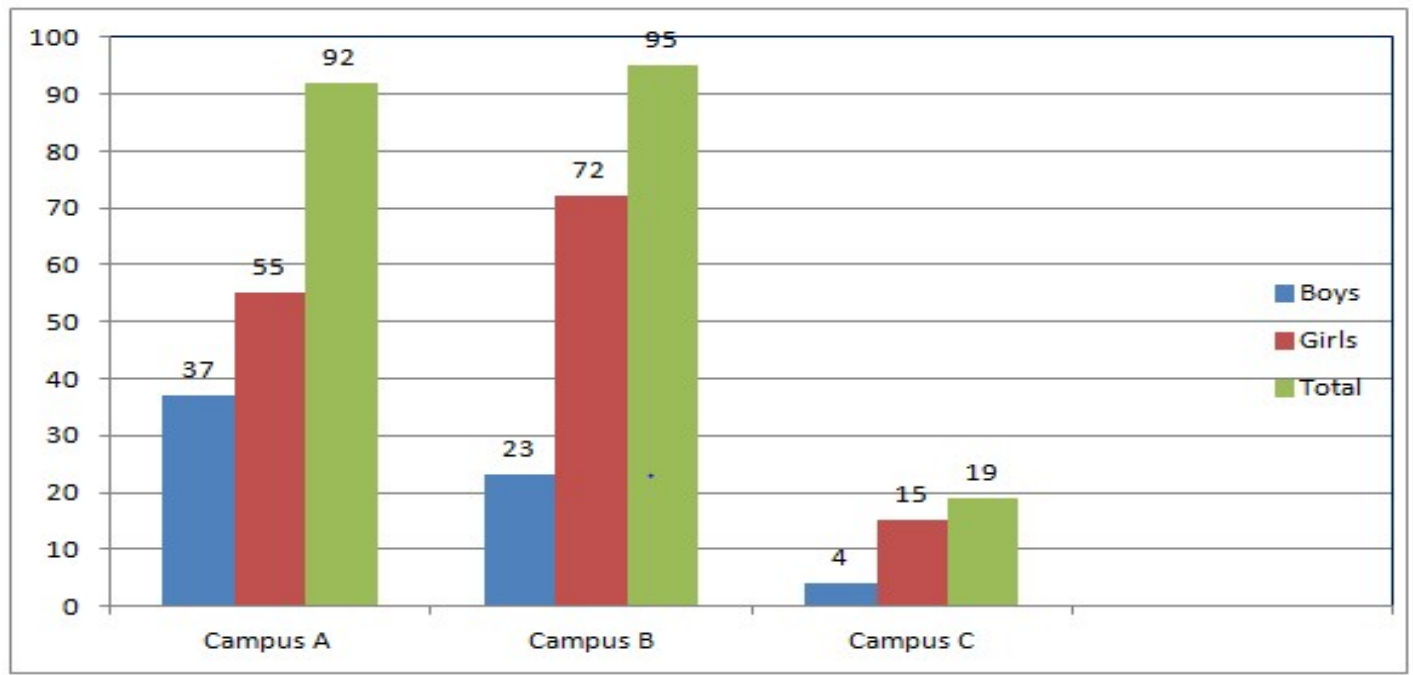

Figure 1. Number of boys and girls selected for the study from three campuses

This figure shows that the number of girls was far higher than that of boys in the study from each campus.

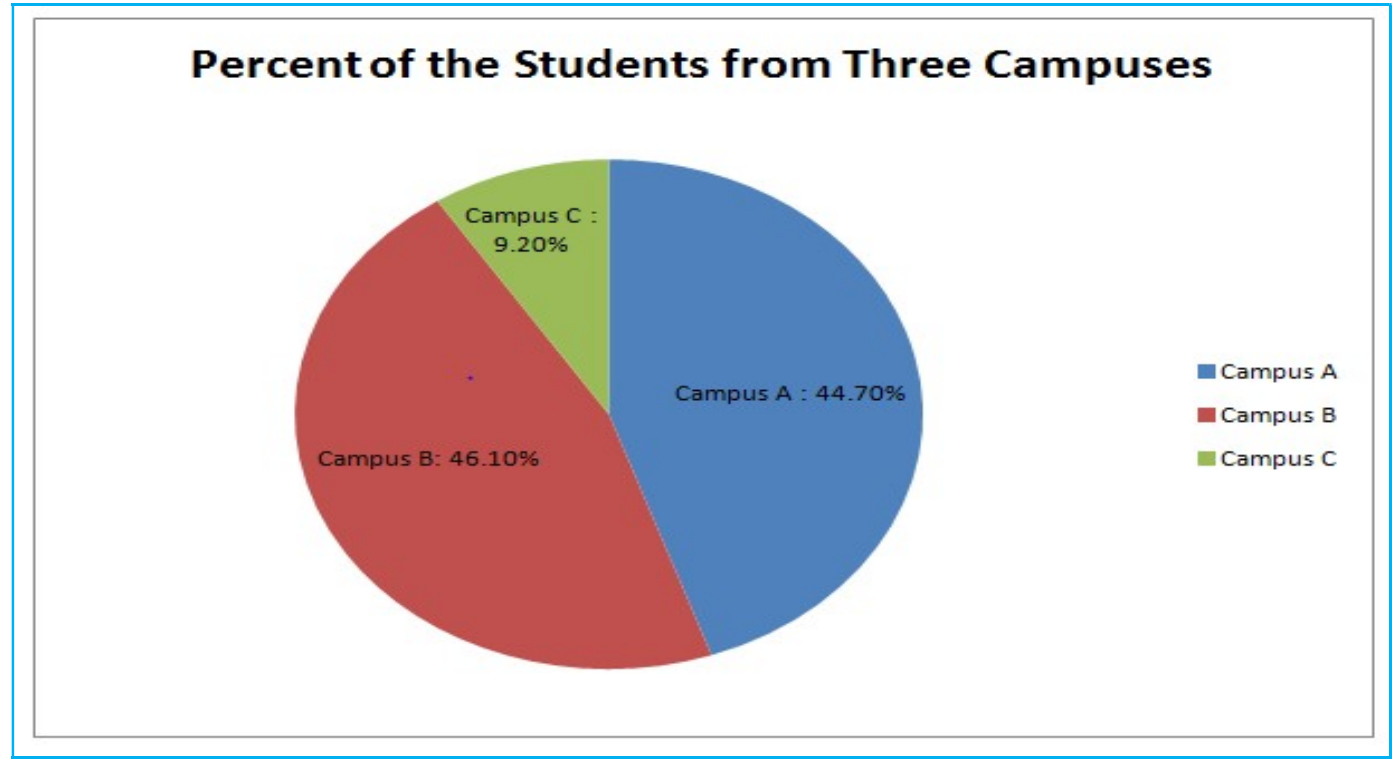

Figure 2. Percent of students by campus

This figure shows that the percent of the students from two campuses was nearly similar; while the percent of students from campus $\mathrm{C}$ was very low. The sample size involved the unequal number or percent of respondents because three campuses had different number of students. Campus B had the largest number of students; whereas campus $\mathrm{C}$ had the lowest number of students. The students were selected randomly from the list after making a complete list of 442 students who formed the population. 


\subsection{Data Collection Procedure}

The students were asked 12 closed- ended questions on students' major motives for learning English cautiously. All the data were analyzed by using SPSS. The researcher used frequency and percent statistics to find out major motives for learning English cautiously. The researcher employed the chi-square tests to assess whether there was statistically significant association between sex and the motives for learning English, and similarly, association between campus and motives for learning it.

\subsection{Presentation of Findings}

The researcher noted twelve motives or reasons for learning English from the students responses. The researcher presented findings of the research in tables and figures.

\section{Table 1}

\section{Motives for Learning English}

\begin{tabular}{|c|c|c|c|c|c|}
\hline $\begin{array}{l}\text { Motive } \\
\text { No. }\end{array}$ & Motive Options & Frequency & Percent & $\begin{array}{c}\text { Valid } \\
\text { Percent }\end{array}$ & $\begin{array}{l}\text { Cumulative } \\
\text { Percent }\end{array}$ \\
\hline 1. & $\begin{array}{l}\text { To attain higher academic } \\
\text { achievement in English education }\end{array}$ & 16 & 7.8 & 7.8 & 7.8 \\
\hline 2. & $\begin{array}{l}\text { To have good job opportunities in } \\
\text { the country }\end{array}$ & 48 & 23.3 & 23.3 & 31.1 \\
\hline 3. & $\begin{array}{l}\text { To go to foreign countries for good } \\
\text { work }\end{array}$ & 37 & 18.0 & 18.0 & 49.1 \\
\hline 4. & To make future career advancement & 29 & 14.1 & 14.1 & 63.2 \\
\hline 5. & To be a knowledgeable person & 3 & 1.4 & 1.4 & 64.6 \\
\hline 6. & $\begin{array}{l}\text { To get respect from the other } \\
\text { persons }\end{array}$ & 7 & 3.4 & 3.4 & 68.0 \\
\hline 7. & To impress the other persons & 18 & 8.7 & 8.7 & 76.7 \\
\hline 8. & To be an English teacher & 27 & 13.1 & 13.1 & 89.8 \\
\hline 9. & To talk to foreigners & 3 & 1.4 & 1.4 & 91.2 \\
\hline 10. & To be a tourist guide & 2 & 1.0 & 1.0 & 92.2 \\
\hline 11. & $\begin{array}{l}\text { To learn foreign cultures literature, } \\
\text { and the life style of the people }\end{array}$ & 7 & 3.4 & 3.4 & 95.6 \\
\hline 12. & To develop personality & 9 & 4.4 & 4.4 & 100.0 \\
\hline & Total & 206 & 100.0 & 100.0 & \\
\hline
\end{tabular}

This table shows that the highest number $48(23.3 \%)$ students considered that they would have good job opportunities if they learnt English well, whereas the smallest number 2 $(1.0 \%)$ students learnt it to be a tourist guide. $16(7.8 \%)$ students had the intention of learning it to attain their higher academic achievement in English education, and the second largest number $37(18.0 \%)$ students expressed their desire of learning it to go to foreign countries for good work to earn more money. The third largest number 29 (14.0\%) students opined that they could make their future career advancement with the help of good English . Very few number $3(1.4 \%)$ students opined to learn it to be knowledgeable persons and intended to talk to foreigners. 7 (3.4\%), students learnt it for getting respect, and for learning foreign cultures, literature and life style of the people ; $9(4.4 \%)$ students intended to learn it for developing their personality. Similarly, 18 (8.7\%) learnt it to impress other people, and 27(13.1\%) learnt it , because they wanted to be English teachers. 
Table 2

Sex and Motives for Learning English

\begin{tabular}{|c|c|c|c|c|c|c|c|c|c|c|c|c|c|c|}
\hline & \multicolumn{12}{|c|}{ Motives for Learning the English Language } & \multirow[b]{2}{*}{ Total } \\
\hline & & M.1 & M.2 & M.3 & M.4 & M.5 & M.6 & M.7 & M.8 & M.9 & M.10 & M.11 & M.12 & \\
\hline \multirow[t]{2}{*}{ Students } & Boys & 2 & 9 & 36 & 2 & 1 & 2 & 0 & 5 & 3 & 2 & 2 & 0 & 64 \\
\hline & Girls & 14 & 39 & 1 & 27 & 2 & 5 & 18 & 22 & 0 & 0 & 5 & 9 & 142 \\
\hline \multicolumn{2}{|c|}{ Total } & 16 & 48 & 37 & 29 & 3 & 7 & 18 & 27 & 3 & 2 & 7 & 9 & 206 \\
\hline
\end{tabular}

Hints: M.1 = Motive Number 1, M. 2 = Motive Number 2 and so on.

This table demonstrates that most of the boys learnt it to go to foreign countries for good work, and most of the girls learnt it well to have good job opportunities in the country. No boy learnt it to impress the other persons and to develop their personality. Similarly, no girl learnt it to talk to foreigners and to be a tourist guide.

Table 3

Campus and Motives for Learning English

\begin{tabular}{|c|c|c|c|c|c|c|c|c|c|c|c|c|c|c|}
\hline & \multicolumn{12}{|c|}{ Motives for Learning the English Language } & \multirow[b]{2}{*}{ Total } \\
\hline & & M.1 & M.2 & M.3 & M.4 & M.5 & M.6 & M.7 & M.8 & M.9 & M.10 & M.11 & M.12 & \\
\hline \multirow{3}{*}{ Campus } & $\mathbf{A}$ & 8 & 20 & 15 & 11 & 0 & 6 & 7 & 13 & 0 & 2 & 6 & 4 & 92 \\
\hline & B & 7 & 22 & 19 & 16 & 3 & 1 & 9 & 11 & 2 & 0 & 1 & 4 & 95 \\
\hline & $\mathbf{C}$ & 1 & 6 & 3 & 2 & 0 & 0 & 2 & 3 & 1 & 0 & 0 & 1 & 19 \\
\hline \multicolumn{2}{|c|}{ Total } & 16 & 48 & 37 & 29 & 3 & 7 & 18 & 27 & 3 & 2 & 7 & 9 & 206 \\
\hline
\end{tabular}

This table depicts that most of the students studying at the three campuses learnt it to have good job opportunities in the country. The second largest number of students learnt it to go to foreign countries for good work. No student at campus A learnt it to be a knowledgeable person and to talk to foreigners. No student at campus B learnt it to be tourist guide.

Similarly, no student at campus $\mathrm{C}$ learnt it to be a knowledgeable person, to get respect from other persons, to be tourist guide, and to learn foreign cultures, literature etc.

\subsection{Chi-Square $(\chi 2)$ Test for the Hypothesis Test}

The chi-square test was designed to determine whether two categorical variables were independent or related. The tests employed the data that were expressed in frequencies. The table or critical value of Chi-square was calculated by using this software: https://www.danielsoper.com/statcalc/calculator.aspx?id=12. According to this software, the critical value of chi-square $\chi^{2}$ (11) is 11.675 , and that of chi-square $\chi 2$ (22) is 33.924 by considering the significance (probability) level at .05. 


\section{Table 4}

\section{Chi-square Test for Sex and the Motives for English}

\begin{tabular}{|l|c|c|c|}
\hline & Value & df & Asymp. Sig. (2-sided) \\
\hline Pearson Chi-Square & $114.967^{\mathrm{a}}$ & 11 & .000 \\
\hline Likelihood Ratio & 126.713 & 11 & .000 \\
\hline Linear-by-Linear Association & 3.672 & 1 & .055 \\
\hline N of Valid Cases & 206 & & \\
\hline
\end{tabular}

a. 12 cells $(50.0 \%)$ have expected count less than 5. The minimum expected count is .62 . Observed Pearson Chi-Square test $\chi \mathbf{2}(11)=114.967$ was larger than the critical value of ChiSquare 19.675, and Sig. (2-tailed) or $p=.000$ that was smaller than .05. This shows us that there was statistically significant association between Sex and the motives for learning English well. The result of the Chi-Square test of Independence rejected the null hypothesis that there was no statistically significant association between Sex and the motives for learning English well. It means boys and girls learnt English for different purposes.

\section{Table 5}

\section{Symmetric}

\section{Measures}

\begin{tabular}{|c|c|c|c|}
\hline \multicolumn{2}{|c|}{} & Value & Approx. Sig. \\
\hline \multirow{2}{*}{ Nominal by Nominal } & Phi & .747 & .000 \\
\cline { 2 - 4 } & Cramer's V & .747 & .000 \\
\hline \multicolumn{2}{|c|}{ N of Valid Cases } & 206 & \\
\hline
\end{tabular}

Phi and Cramer's V are both tests of the strength of association. The table shows that the strength of association between Sex and the motives for learning the English language was strong (.747).

\section{Table 6}

\section{Chi-square Test for Campus and the Motives for Learning English}

\begin{tabular}{|l|c|c|c|}
\hline & Value & df & Asymp. Sig. (2-sided) \\
\hline Pearson Chi-Square & $22.111^{\mathbf{a}}$ & 22 & .453 \\
\hline Likelihood Ratio & 25.802 & 22 & .260 \\
\hline Linear-by-Linear Association & .523 & 1 & .470 \\
\hline N of Valid Cases & 206 & & \\
\hline
\end{tabular}

Observed Pearson Chi-Square test $\chi 2(22)=22.111$ was smaller than the critical value of Chi-Square 33.924, and Sig. (2-tailed) or $p=.453$ was larger than .05 . This shows us that there was no statistically significant association between Campus and the motives for learning the English language. The result of the Chi-Square test of Independence accepted the null hypothesis that there was no statistically significant association between Campus and the motives for learning it. 


\section{Table 7}

\section{Symmetric}

\section{Measures}

\begin{tabular}{|c|c|c|c|}
\hline \multicolumn{2}{|c|}{} & Value & Approx. Sig. \\
\hline \multirow{2}{*}{ Nominal by Nominal } & Phi & .328 & .453 \\
\cline { 2 - 4 } & Cramer's V & .232 & .453 \\
\hline \multicolumn{2}{|c|}{ N of Valid Cases } & 206 & \\
\hline
\end{tabular}

Phi and Cramer's V are both tests of the strength of association. The table demonstrates that the strength of association between Campus and the reasons for learning English was weak.

\section{RESULT AND DISCUSSION}

Frequency and percent statistics showed that most of the boys $36(56.25 \%)$ learnt the English language to go to foreign countries for good work, and most of the girls $39(27.46 \%)$ learnt it to have good job opportunities in the country. No boy learnt it to impress the other persons and to develop their personality. Similarly, no girl learnt it to talk to foreigners and to be a tourist guide. Most of the students $20(21.73 \%)$ at campus A, $22(23.15 \%)$ at campus B and $6(31.57 \%)$ at Campus $\mathrm{C}$ learnt it to have good job opportunities in the country. The second largest number of students $15(16.30 \%)$ at campus A, $19(20.00 \%)$ at campus B and 3 $(15.78 \%)$ at campus $\mathrm{C}$ learnt it to go to foreign countries for good work. No student at campus A learnt it to be a knowledgeable person and to talk to foreigners. No student at campus B learnt it to be tourist guide. Similarly, no student at campus $\mathrm{C}$ learnt it to be a knowledgeable person, to get respect from other persons, to be tourist guide, and to learn foreign cultures, literature etc. Most of the Hindu students $42(23.33 \%)$ learnt it to have good job opportunities in the country. Most of the Buddhist students $5(2.83 \%)$ learnt it to have good job opportunities in the country, and to go to foreign countries for good work. The Christian students expressed their intention of learning it for good job opportunities and for impressing the other persons.

The result of the chi-square test of independence shows that there was statistically significant association between Sex and the motives for learning the English language [ $\chi^{2}$ $(11)=114.976$, critical value $=19.675 \& p=.000$ ], whereas there was no statistically significant association between campus and motives for learning it $[\chi 2(22)=22.111$, critical value $=33.924 \& p=.453]$. The empirical review of literature also showed that motives of the students for learning the English language were varied.

There are some possible reasons for these research findings. Firstly, most of the students in the present time are motivated towards their jobs. With the knowledge of English, they think that they may entertain more job opportunities. Secondly, some of the students want to earn more money by working in foreign countries. Our country can't provide the job holders with handsome salaries and other facilities. A few students desire to learn English for future career advancement. They still hope that their knowledge of English education will help them in their field. In fact, the reasons for learning English depend on the students' family 
backgrounds, the condition of the country, motivational factors, peers, their own intuition and so on.

\section{CONCLUSION}

The research study shows the students' dissimilar motives for learning the English language depending on the students' backgrounds, attitudes towards the English language, motivation and goals of their lives. The research studied was based on the twelve motives for learning it .The study shows that most of students learnt it to have good job opportunities in the country. This study portrays the real situation of students. Boys wanted to go to foreign countries to earn more money with the help of their good English, whereas girls desired to have jobs in the country. The chi-square tests clearly depict that most of the boys and the girls had different motives for learning the English language. It means there was statistically significant association between sex and the reason for learning English language, but there was no statistically significant association between campus and religion with the motives for learning. Results of the study indicate that most of the students were instrumentally motivated towards learning the English language. The result of this study may be suggestive for the English course developers for drafting a practical course that can help the students in attaining their goals through learning. They need to include in the course the contents and exercises that are instrumentally useful to the students. The research further suggests adopting communicative and discussion approaches to teaching rather than lecture method so that they can learn English well as a pivotal part of learning. The teachers need to encourage their students to take part in interaction and discussion so that they will think they are both learning and entertaining the lesson. Future researchers are recommended to carry out further research studies to find out the students' motives for learning English.

\section{REFERENCES}

Ahmed, M., Aftab, M., \& Yaqoob, H. (2015). Students' motivation toward Englislearning at undergraduate leve. Advances in Language and Literary Studies, 6(3), 1-9.

Akcay, A., Butuner, T., \& Arikan, A. (2015). Reasons behind young learners' learning of foreign languages. International Journal of Language Academy, 3(2), 56-68.

Al Mamun, Rahman, Rahman, \& Hossain. (2012). Students' attitudes towards English: The case of life science school of Khulna University. International Review of Social Sciences and Humanities, 3(1), 200-209.

Al-Quyadi, A. (2000). Psycho-sociological variables in the learning of English in Yemen. (Ph. D. thesis). . Bhagalpur University.

Al-Tamim, A., \& Shuib, M. (2009). Motivation and attitudes towards learning English: A study of petroleum engineering undergraduates at Hadhramout University of sciences and technology. GEMA- Online Journal of Language Studies, 9(2), 29-55.

Anderson, J., \& Lindkvist, J. (2000). Education in Nepal: A study of Nepalese teachers' view on their school situation. Sweden: Linkoping University.

Awasthi, J. (1979). ELT in Nepal: A sociolinguistic survey. India: Central Institute of Indian. India: Central Institute of Indian. 
Bhattarai, G. R. \& Gautam, G. R. (3003, as cited in Bhattarai \& Gautam, 2007). Bhattarai, G. R. \& Gautam, G. R. (2007). The proposed ELT survey: Redefining status and role of English in Nepal. Journal of NELTA, 12(1), 32-35.

Bhattarai, G. R. (2006). English teaching situation in Nepal: Elaboration of the theme for panel discussion in the 40th TESOL conference. Journal of NELTA, 11(1-2), 11-16.

Bista, K. (2011). Teaching English as a foreign/second language :Past and present. English for Specific Purposes World, 11(32), 1-9.

Bobkina, J., \& Fernandez de, M. (2012). Motivation and attitudes towards learning English: A study of engineering undergraduates at the technical university of Madrid. http://library.iated.org/view/BOBKINA2012M. ICERI2012 Proceedings, 4492-4501.

Boniadi, A. M., \& Rahmatvand, N. (2013). Problems of English for specific purpose course for medical students in Iran. Khazar Journal of Humanities \& Social Sciences, 16(1), 48-55.

Brewer, E. W., \& Burgess, D. N. (2005). Professor's role in motivating students to attend class. Journal of Industrial Teacher Education, 42(3), 1-24.

Brown, H. (1994). . Principles of language learning and teaching (3rd ed.). Eaglewood Cliff: Prentice Hall Regents.: Eaglewood Cliff: Prentice Hall Regents.

Chalak, A., \& Kassaian, Z. (2010). Motivation and attitudes of iranian undergraduate efl students towards learning English. Journal of Language Studies 37, 10(2), 37-56. Retrieved from http://ejournals.ukm.my/gema/article/view/108/99

Chew, F. (2013). Language attitudes of university students in China. Language Learning, 68(16), 89-97. doi:DOI: 10.7763/IPEDR

Crow, L., \& Crow, A. (1973). Educational psychology. New Delhi: Eurasia Publishing House.

Gardner, R. C. (2006). The socio-educational model of second language acquisition: A research paradigm. EUROSLA Yearbook, 6, 237-260.

Gardner, R. C., \& Lambert, W. E. (1972). Attitudes and motivation in second-language learning. Rowley, MA: Newbury House Publishers.

Giri, R. A. (2010). English language teachers' resource centre: A model for developing contexts. Journal of NELTA. Journal of NELTA, 15(1 \& 2), 64-76.

Giri, R. A. (2014). Changing faces of English: Why English is not a foreign language in Nepal. Journal of World Languages, 1(3), 192-209. doi:

10.1080/21698252.2014.989643

Giri, R. A. (2015). The many faces of English in Nepal. Asian Englishes, 17(2), 94-115.

Goharimehr, N. (2017). Identity, motivation and English learning in a Japanese context. World Journal of English Language, 7(4), 18-30.

Harmer, J. (1990). The practice of English language teaching. Harlow: Longman. Harlow: Longman.

Hedge, T. (2000). Teaching and learning in the language classroom. New York: Oxford University Press.

Jha, A. K. (1989). The Teaching of Contemporary English in Nepal. The Window, 2(1), 7072. 
Johnstone, K. (1999). Research on language learning and teaching: Language Learning. London: Routledge.

Kaharan, F. (2007). Language attitudes of Turkish students towards the English language and its use in Turkish context. Journal of Arts and Sciences. Journal of Arts and Sciences, 73-87.

Khatri, K. K. (2019). Teachers' attitudes towards English as medium of instruction. Journal of NELTA Gandaki (JoNG), 2, 43-54.

Krashen, S. (1985). The input hypothesis: Issues and implications. California: Laredo Publishing Co Inc.

Maharjan, L. B. (2009). Learners' errors and their evaluation. Journal of NELTA, 14(1-2), 71 81.

Mahreez, A. (1994). The factors influencing the Malaysian Chinese attitudes towards leaning English as a second language. (M.A. thesis). University of Essex. University of Essex. Retrieved from http://etd.uum.edu.my/608/

Mahu, D. (2012). Why is learning English so beneficial nowadays? International Journal of Communication Research, 2(4), 374-376.

Malla, K. (1977). English in Nepalese Education. Kathmandu: Ratna Pustak Bhandar. Kathmandu: Ratna Pustak Bhandar.

Mohd Sallehhudin, A. (1994). Attitude towards English: A Survey of UKM undergraduates http://www.ukm.my/penerbit/akademika/jakad_44-05-pdf. Akademika, 44, 85-99. Retrieved from http://www.ukm.my/penerbit/akademika/jakad_44-05-pdf

Nishanthi, R. (2018). The importance of learning in today world. International Journal of Trend in Scientific Research and Development, 3(1), 871-874.

Ojha, L. P. (2018). Shifting the medium of instruction to English in community schools: Policies, practices and challenges in Nepal. In Hayes, David (Ed.), English Language Teaching in Nepal: Research. Research, Reflection and Practice, 187-200.

Paudel, T. ( 1988, as cited in Poudel, 2016). English in Nepal: From colonial legacy to professionalism. ELT Chautari. Retrieved from http://eltchoutari.com/2016/01/english-in-nepal-from-colonial-legacy-toprofessionalism.

Pressey, S. R., \& Horrocks, J. (1967). Psychology in education. New Delhi: University Book Stall. New Delhi: University Book Stall.

Rao, V. (2018). The use of English language in research. Journal for Research Scholars \& Professionals of English Language Teaching, 2(8), 1-8.

Rehman A., B. H., \& A, N. (2014). The role of motivation in learning English language for Pakistani learners. International Journal of Humanities and Social Science, 4(1), 254 258.

Rehman, A. S., \& Nawaz, A. (2014). The role of motivation in learning English language for Pakistani learners. International Journal of Humanities and social Science, 4(1), 254258.

Ryan, R. M., \& Deci, E. (2000). Self-determination theory and the facilitation of intrinsic motivation, social development, and well being. American Psychologist, 55, 8-78. 
Sali, P. (2012). Understanding motivations to become teachers of English: ELT trainees' perceptions. Paper presented at the 3rd World Conference on Learning, Teaching and Educational Leadership (WCLTA-2012). .

Sharma, G. P. (1990). The impact of education during the Rana Period in Nepal. Himalaya, the Journal of the Association for Nepal and Himalayan Studies, 10, 2-6.

Sharma, K. C. (2006). English in Nepal from the past to present. Journal of NELTA, 11(1), 24-33.

Shrestha, K. N. (2017). English in Nepal: From a guest language to the best language. NELTA ELT Forum August 5. NELTA ELT Forum August 5, 1-10.

Tabatabaei, O., \& Mokhtari, A. (2014). ESP learners' perception of ESP program problems at Iranian universities: A case study of Islamic Azad university Najafabad branch. Theory and Practice in Language Studies, 4(6), 1144-1154.

Tahaineh, Y., \& Daana, H. (2013). Jordanian undergraduates' motivations and attitudes towards learning English in EFL context http://www.irssh.com/yahoo_site_adm. International Review of Social Sciences and Humanities, 4(2), 159-180. Retrieved from http://www.irssh.com/yahoo_site_admin/assets/docs/ 15 IRSSH-433-V4 N2.44203943.pdf

Thapa, A. (2011). Does private school competition improve public school performance? The case of Nepal. Unpublished PhD thesis, Columbia University, USA.

Vaezi, Z. (2008). Language learning motivation among Iranian undergraduate students. World Applied Sciences Journal, 5, 54-61.

Yang, X. (2012). Attitude and motivation in L2 learning among UM master students. International Journal of Management and Sustainability, 1(1), 13-22. Retrieved from http://www.pakinsight.com/pdffiles/ ijms\%20pp.13-22.pdf 